\title{
Profile of professionals working in physical activity interventions within programs in the primary health care system in the State of Pernambuco
}

\author{
Perfil dos profissionais que atuam nos programas de promoção da saúde \\ com intervenções em atividade física da atenção básica à saúde do \\ estado de Pernambuco
}

\author{
Danyelle de Cássia Ribeiro de Oliveira ${ }^{1,2}$, Anísio Luiz da Siva Brito², Rafael Miranda Tassitano ${ }^{2,3}$
}

\begin{abstract}
The present study aimed to map the profile of professionals actively working in physical activity intervention programs for health promotion within the primary health care system in the State of Pernambuco, according to sociodemographic characteristics, education, continuous education and permanent education. Cross-sectional study conducted in the State with 511 professional (59.1\% women). Time since formal education was achieved, type of employment, curricular experiences in initial education, participation in events, lectures and courses focusing in physical education, as well as the social and demographic characteristics were collected through a built and previously validated questionnaire. Descriptive and inferential analysis were conducted, and chi-square test considered a $p$ value of $<0.05$. Most professionals $(92.8 \%$ ) have completed higher education, being $61.2 \%$ in Physical Education, $64.3 \%$ with up to six years of work in primary health care and $67.3 \%$ employed temporarily. A larger proportion of professional with State employment within the Health Secretary was observed for Physical Education rather than other areas of education $(\mathrm{p}<0.05)$. About $37.8 \%$ of professionals reported not having educational experience in primary health care while in undergraduate education and $69.2 \%$ participated in events, courses and lectures related to physical activity. It is possible to identify frailty in primary education of professionals as well as continued education. Investments in training may strengthen professional work in public policy programs emphasizing in physical activity.
\end{abstract}

\section{Keywords}

Motor Activity; Primary Health Care; Health Human Resources; Continuing Education.

\section{Resumo}

O presente estudo teve como objetivo realizar um mapeamento do perfil quanto às características sociodemográficas, de formação inicial, formação continuada e educação permanente dos profissionais que atuam em programas de promoção da saúde com intervenções em atividade física da atenção básica do Estado do Pernambuco. Estudo transversal de abrangência estadual com 511 profissionais (59,1\% de mulheres). Tempo de formação, de atuação profissional, tipo de vínculo, experiências curriculares na formação inicial, participação em eventos, palestras e cursos com foco na atividade física, bem como as características sociais e demográficas foram coletadas através de um questionário construído e previamente validado. Foram realizadas análises descritivas e para as análises inferenciais o teste de Qui-quadrado, considerando um $p<0,05$. A maioria dos profissionais (92,8\%) tem formação superior completa, sendo 61,2\% em Educação Física, 64,3\% com até seis anos de atuação na atenção básica e 67,3\% contratado de forma temporária. Uma maior proporção de profissionais com vínculo estatutário na Secretaria de Saúde foi observada entre os licenciados plenos em Educação Física quando comparado às demais formações iniciais ( $p<0,05)$. Cerca 37,8\% dos profissionais relataram não terem nenhuma experiência curricular na graduação relacionada à atenção básica e 69,2\% participou no último ano de cursos, palestras ou eventos relacionados à atividade física. É possível identificar fragilidade tanto na formação inicial quanto na participação desses profissionais em cursos de formação continuada. Investimentos na formação pode fortalecer a atuação profissional nos programas de políticas públicas com ênfase na atividade física.

\section{Palavras-chave}

Religion; Social Support; Motor Activity; Review.

\section{Introduction}

\footnotetext{
1 Municipal Secretary of Health of Recife - PE/Brazil 2 Graduate Program in Physical Education - UPE/UFPB, Brazil 3 Federal Rural University of Pernambuco - UFRPE, Brazil
}

In 2006, the Ministry of Health (MH) released the National Policy for Health Promotion (NPHP) adding physical activity (PA) as one of the strategies to confront with non-communicable chronic diseases 
(NCDs) $^{1-2}$. In 2008, the Nuclei for Support to Family Health (NSFH) were implemented, which brought to question PA practice as a strategy for integral health care $^{3}$. Starting in 2001, the Academia da Saude (Health Gym) Program also introduced to broaden the promotion of PA, leisure and healthy lifestyles for all municipalities in the country ${ }^{4}$. Before launching NPHP, a few cities offered programs and/or interventions to promote health focused on PA, such as Academia da Cidade (City Gym, in Recife) in 2002, Curitibativa (Curitiba) in 2005, among others ${ }^{5}$.

From this historic context of implementation of the NPHP, as well as the recognition of the Physical Education professional (PEP) in the health sector, the insertion of PEP within the Primary Health Care (PHC) has been observed ${ }^{6,7}$. Recent studies have approached the work and education of such professionals in the $\mathrm{PHC}^{8-11}$ and, in general, indicate forms of intervention and expectation of activities developed ${ }^{12}$. Additionally, there are no studies indicating differences in initial, continued and permanent education of professionals, considering the different careers in Physical Education. In a study by Rodrigues et al., $2015^{8}$, for example, all PEP working in the NSFH in the region of Joao Pessoa in Paraiba are fully licensed. Even though there is proximity with the state of Pernambuco, the reality is distinct and initial education and practices in PHC are different.

In the available literature, as well as in institutional documents, there is no information within the municipality, state or federal on the profile of professionals acting in health promotion programs that emphasize physical activity, according to initial, continued and permanent educational levels. Mapping such information will allow a broader look to the profile of professionals acting in programs and/or interventions. Besides, it might be an important way to make higher education institutions reflect on the rearrangement of initial education of PEP for such field of work.

Therefore, the present study aims to map the profile of professionals working in programs for health promotion in primary health care with interventions in physical activity, regarding to initial, continued and permanent education in the State of Pernambuco.

\section{Methods}

This is a cross-sectional, descriptive statewide study, part of a project entitled "Evaluation of programs and interventions related to PA in the primary health care system in the state of Pernambuco - SUS+Ativo project". The project was submitted and approved by the Ethics Committee in Research with Human Beings of the University of Pernambuco - CAAE: 13373313.5.0000.5207, and participation was volunteer after signing the free consent term.

All professionals working in programs and/or interventions for health promotion constituted the population of this study. The criterion was that, in order to be a part of the study, the programs had to be related to the State or Municipal Secretaries of Health. According to data from September 2013, the State Secretary of Health of Pernambuco informed a total of 164 Nuclei for Support to Family Health (NSFH) distributed in the 12 regional health management (in Portuguese, Geres). Moreover, currently 87 municipalities receive funding from the Ministry of Health for the development of interventions and programs for PA promotion in PHC, such as Academia da Cidade in Recife, Academia das Cidades in Pernambuco, Academia da Saude and municipal programs. More information on the conception, construction and validation of instruments and methods for fieldwork can be found in paper entitles "Evaluation of programs and interventions for physical activity promotion in primary health care in Pernambuco: construction 
and validation of instruments and fieldwork methods of the SUS+Ativo Project"13.

Data collection was undertaken between the months of February and June 2014 and July 2015 and interviews were conducted with a self-report questionnaire entitled "Questionnaire for evaluation of interventions for physical activity promotion in the primary health care system - professional version". Among the dimensions composing the instrument, demographics (gender, age, monthly family income, marital status, race and place of residence); professional experience (type of employment, length of professional experience, length of work in PHC and length of work in PA promotion programs); initial education (area of graduation, time since graduated, type of institution, participation in Pet-Health, ProHealth, curricular internship in PHC, extracurricular internship in PHC, curricular punctual experience in PHC (class, visitation and/or event), scientific initiation related to PHC and extension projects focused on PHC); continued education and permanent education (graduate education, participation in courses, events or workshops in the area of physical activity during the last year).

Data was tabled through optical reading of questionnaires using the software SPHYNX® (Sphynx Software Solutions Incorporation, Washington, United States). All analysis used SPSS software (version 10). Initially, some variables were categorized in the plan of analysis: time since graduation $(\leq 5$ years, $>5$ and $\leq 10$ years and $>10$ years), professional experience ( $\leq 3$ years, $>3$ and $\leq 6$ years, $>6$ years), length of work in PHC ( $\leq 1$ year, $>1$ and $\leq 3$ years, $>3$ years) and length of work in PA promotion programs ( $\leq 1$ year, $>1$ and $\leq 3$ years, $>3$ years), amount of participation in courses, events and workshops in the past 12 months (none, 1 to 2 courses, and 3 or more courses). At last, a variable was created from the sum of curricular activities related to PHC (no experience, 1 to 3 experiences, and 4 to 7 experiences).

After that, descriptive analyses were conducted to determine frequency (absolute and relative) for categorical variables and means (standard deviations) for continuous variables. Inferential analyses used chi-square test and chi-square for tendency, in order to verify association between area of graduation and the variables from the dimensions evaluated in this study. All tests considered $\mathrm{p}<0.05$ for level of significance.

\section{Results}

A total of 511 professionals were interviewed (92.8\% with formal higher education), mostly female (59.6\%) with a mean age and respective standard deviation of 31.9 years $(\mathrm{SD} \pm 7.6)$. During data collection, 10 participants were lost, one due to vacation, four were on leaves and the remaining did not show in the date set for the interview. Moreover, two professionals refused to participate. From the total of professionals, $1.2 \%$ is from Physical Education and 6.0\% reported not having concluded initial education. Additional information on demographics, economic characteristics of professionals with higher education working in interventions and/ or programs for PA promotion in the state of Pernambuco are shown in table 1.

On initial education, six in every ten majored in Physical Education, being 39.0\% fully licensed (bachelor in school education and fitness), $12.6 \%$ licensed (bachelor in school education) and 9.6\% with a bachelor in fitness. Other fields of initial education were: social assistant, pharmacy, nurse, physical therapy, psychology, occupational therapy, nutrition, odontology, and phono audiology. About four in every ten professionals reported working for over 6 years, independent of being in PHC. Fewer have up to a year in experience in PHC (24.5\%) and in programs for PA promotion (30.7\%). Most (67.3\%) professionals are hired temporarily and only $28.1 \%$ are public employees to Secretaries of Health. A significant difference was 
found between licensed Physical Education professionals and all other majors, when relating to having State employment with the Secretary of Health $(\mathrm{p}<0.05)$. In figure 1 data related to type of employment with the intervention and/or program for PA promotion are presented, stratified by initial education.

TABLE 1 - Demographics characteristics of professionals with complete higher education working in programs and interventions for physical activity promotion in PHC in the State of Pernambuco, stratified by education (major).

\begin{tabular}{|c|c|c|c|c|c|c|c|c|}
\hline \multirow[t]{2}{*}{ Variables } & \multicolumn{2}{|c|}{$\begin{array}{l}\text { Bachelor in Physical } \\
\text { Education (Fitness) }\end{array}$} & \multicolumn{2}{|c|}{$\begin{array}{l}\text { Full License in Physical Education } \\
\text { (school education and fitness) }\end{array}$} & \multicolumn{2}{|c|}{$\begin{array}{l}\text { License in Physical Education } \\
\text { (school education) }\end{array}$} & \multicolumn{2}{|c|}{$\begin{array}{l}\text { Other higher education } \\
\text { major * }\end{array}$} \\
\hline & $n$ & $\%$ & $n$ & $\%$ & $n$ & $\%$ & $n$ & $\%$ \\
\hline $\begin{array}{l}\text { Gender } \\
\text { Male } \\
\text { Female }\end{array}$ & $\begin{array}{l}21 \\
24\end{array}$ & $\begin{array}{l}46.7 \\
53.3\end{array}$ & $\begin{array}{c}106 \\
89\end{array}$ & $\begin{array}{l}54.4 \\
45.6\end{array}$ & $\begin{array}{l}29 \\
18\end{array}$ & $\begin{array}{l}61.7 \\
38.3\end{array}$ & $\begin{array}{c}31 \\
151\end{array}$ & $\begin{array}{l}17.0 \\
83.0\end{array}$ \\
\hline $\begin{array}{l}\text { Marital Status } \\
\text { Single } \\
\text { Married } \\
\text { Other }\end{array}$ & $\begin{array}{c}26 \\
16 \\
2 \\
\end{array}$ & $\begin{array}{c}59.1 \\
36.4 \\
4.5 \\
\end{array}$ & $\begin{array}{c}65 \\
119 \\
10 \\
\end{array}$ & $\begin{array}{c}33.5 \\
61.3 \\
5.2 \\
\end{array}$ & $\begin{array}{c}28 \\
16 \\
3\end{array}$ & $\begin{array}{c}59.6 \\
34 \\
6.4\end{array}$ & $\begin{array}{c}99 \\
74 \\
9\end{array}$ & $\begin{array}{c}54.4 \\
37.3 \\
6.8 \\
\end{array}$ \\
\hline $\begin{array}{l}\text { Race/Color } \\
\text { White } \\
\text { Black } \\
\text { Asian } \\
\text { Brown } \\
\text { Indigenous }\end{array}$ & $\begin{array}{c}19 \\
5 \\
3 \\
17 \\
1\end{array}$ & $\begin{array}{c}42.2 \\
11.1 \\
6.7 \\
37.8 \\
2.2 \\
\end{array}$ & $\begin{array}{c}82 \\
21 \\
10 \\
79 \\
2\end{array}$ & $\begin{array}{l}42.1 \\
10.8 \\
5.1 \\
4.5 \\
1.0\end{array}$ & $\begin{array}{c}14 \\
4 \\
3 \\
26 \\
0\end{array}$ & $\begin{array}{c}29.8 \\
8.5 \\
6.4 \\
55.3 \\
0\end{array}$ & $\begin{array}{c}98 \\
9 \\
10 \\
63 \\
1\end{array}$ & $\begin{array}{c}54.1 \\
5.0 \\
5.5 \\
34.8 \\
1.0\end{array}$ \\
\hline $\begin{array}{l}\text { Monthly family income } \\
\text { From } 1 \text { to } 4 \\
4 \text { or more }\end{array}$ & $\begin{array}{l}27 \\
18\end{array}$ & $\begin{array}{l}60.0 \\
40.0\end{array}$ & $\begin{array}{c}67 \\
128\end{array}$ & $\begin{array}{l}34.4 \\
65.6\end{array}$ & $\begin{array}{l}32 \\
15\end{array}$ & $\begin{array}{l}68.1 \\
31.9\end{array}$ & $\begin{array}{c}90 \\
49.5\end{array}$ & $\begin{array}{c}92 \\
50.5\end{array}$ \\
\hline $\begin{array}{l}\text { Residence located near work } \\
\text { Yes } \\
\text { No }\end{array}$ & $\begin{array}{l}29 \\
14\end{array}$ & $\begin{array}{l}67.4 \\
32.6\end{array}$ & $\begin{array}{c}133 \\
53\end{array}$ & $\begin{array}{l}71.5 \\
28.5\end{array}$ & $\begin{array}{c}39 \\
6\end{array}$ & $\begin{array}{l}86.7 \\
13.3\end{array}$ & $\begin{array}{l}97 \\
79\end{array}$ & $\begin{array}{l}55.1 \\
44.9\end{array}$ \\
\hline
\end{tabular}

*Social assistant, Pharmacy, Nursing, Physical Therapy, Psychology, Occupational Therapy, Nutrition, Phono audiology; ** Minimum wage at the time was $\mathrm{R} \$ 788.00$.

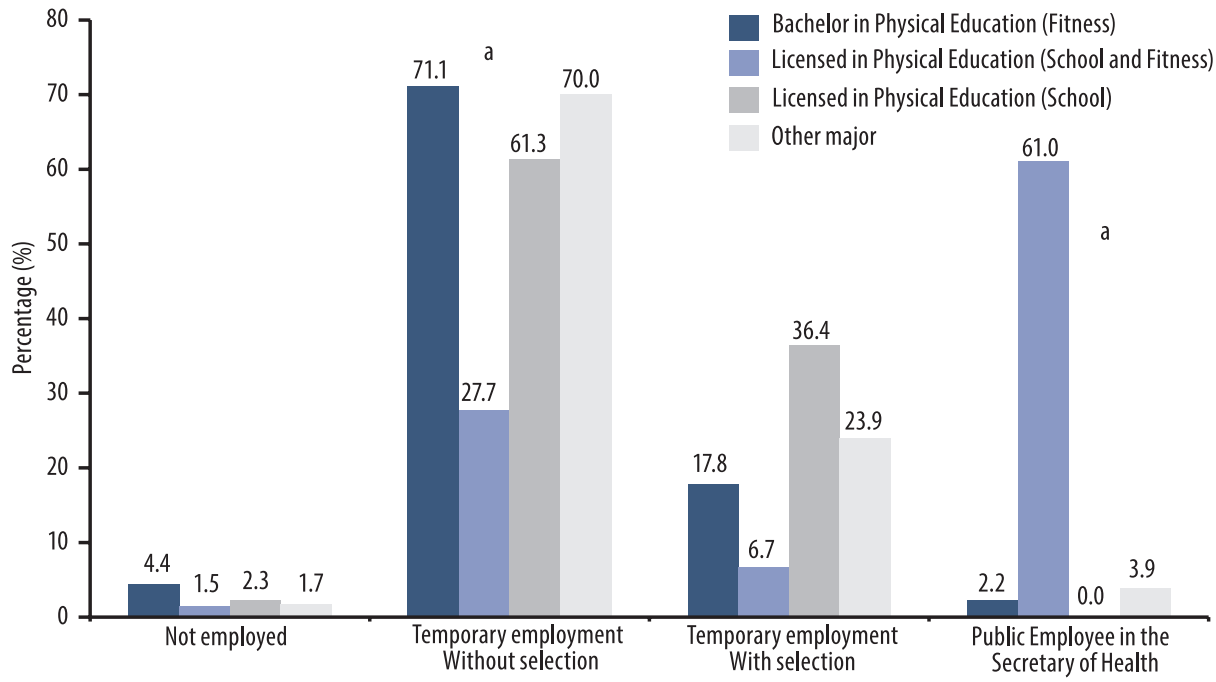

FIGURE 1 - Type of employment of professionals working in health promotion programs in PHC, with interventions in physical activity in the state of Pernambuco, by initial education.

$\mathrm{a}=$ significant difference between full license in Physical Education when compared to other categories of initial education. Note: Other type of employment was 4.5\% for bachelors, 3.1\% for fully licensed and $0.5 \%$ for other initial education.

From professionals with complete higher education, $45.7 \%$ presented complete post-graduation in Lato Sensu, 3.0\% multiprofessional residency in health and $2.6 \%$ academic master's degree. In experiences during initial education, most professionals did not participate in activities such as PET-Health (93.5\%), PRO- 
Health (96.1\%), obligatory curricular internship in PHC (62.8\%), non-obligatory curricular internship in PHC (70.5\%), scientific initiation focused on PHC (86.5\%), any curricular experience focused on PHC (50.5\%) and university extension focused on PHC (83.4\%). Additional information about professional experiences of those with complete higher education can be observed on table 2.

TABLE 2 - Characteristics of initial education of professionals with higher education working in programs for health promotion in PHC, with interventions in physical activity in the state of Pernambuco.

\begin{tabular}{|c|c|c|c|c|c|c|c|c|c|}
\hline \multirow[t]{2}{*}{ Variables } & \multicolumn{2}{|c|}{$\begin{array}{l}\text { Bachelor in Physical } \\
\text { Education (Fitness) }\end{array}$} & \multicolumn{2}{|c|}{$\begin{array}{c}\text { Full License in Physical } \\
\text { Education (school education } \\
\text { and fitness) }\end{array}$} & \multicolumn{2}{|c|}{$\begin{array}{l}\text { License in Physical } \\
\text { Education (school } \\
\text { education) }\end{array}$} & \multicolumn{2}{|c|}{$\begin{array}{c}\text { Other higher } \\
\text { education major * }\end{array}$} & \multirow[t]{2}{*}{$p$} \\
\hline & $n$ & $\%$ & $n$ & $\%$ & $\mathrm{n}$ & $\%$ & $n$ & $\%$ & \\
\hline $\begin{array}{l}\text { Initial Education } \\
\text { Public institution } \\
\text { Private institution }\end{array}$ & $\begin{array}{c}9 \\
36\end{array}$ & $\begin{array}{l}20.0 \\
80.0\end{array}$ & $\begin{array}{l}150 \\
44\end{array}$ & $\begin{array}{l}77.3 \\
22.7\end{array}$ & $\begin{array}{c}8 \\
38\end{array}$ & $\begin{array}{l}17.4 \\
82.6\end{array}$ & $\begin{array}{c}38 \\
143\end{array}$ & $\begin{array}{l}21.0 \\
79.0\end{array}$ & $<0.05^{a}$ \\
\hline $\begin{array}{l}\text { Time since graduation } \\
\leq 5 \text { years } \\
>5 \text { and } \leq 10 \text { years } \\
>10 \text { years }\end{array}$ & $\begin{array}{c}29 \\
14 \\
1\end{array}$ & $\begin{array}{l}65.9 \\
31.8 \\
2.3\end{array}$ & $\begin{array}{c}23 \\
105 \\
65\end{array}$ & $\begin{array}{l}11.9 \\
54.4 \\
33.7\end{array}$ & $\begin{array}{l}35 \\
8 \\
0\end{array}$ & $\begin{array}{c}81.4 \\
18.6 \\
0\end{array}$ & $\begin{array}{l}90 \\
55 \\
31\end{array}$ & $\begin{array}{l}51.1 \\
31.2 \\
17.6\end{array}$ & $<0.05^{\mathrm{a}}$ \\
\hline $\begin{array}{l}\text { Professional experience } \\
\leq 3 \text { years } \\
>3 \text { and } \leq 6 \text { years } \\
>6 \text { years }\end{array}$ & $\begin{array}{c}16 \\
24 \\
3\end{array}$ & $\begin{array}{l}37.2 \\
55.8 \\
7.0\end{array}$ & $\begin{array}{c}13 \\
45 \\
136\end{array}$ & $\begin{array}{c}6.7 \\
23.2 \\
70.1 \\
\end{array}$ & $\begin{array}{r}16 \\
21 \\
9\end{array}$ & $\begin{array}{l}34.8 \\
45.7 \\
19.6 \\
\end{array}$ & $\begin{array}{l}77 \\
55 \\
48\end{array}$ & $\begin{array}{l}42.8 \\
30.6 \\
26.7\end{array}$ & $<0.05^{a}$ \\
\hline $\begin{array}{l}\text { Length of time working in } \mathrm{PHC} \\
\leq 1 \text { year } \\
>1 \text { and } \leq 3 \text { years } \\
>3 \text { years }\end{array}$ & $\begin{array}{c}15 \\
16 \\
8\end{array}$ & $\begin{array}{l}38.5 \\
41.0 \\
20.5\end{array}$ & $\begin{array}{l}18 \\
83 \\
83\end{array}$ & $\begin{array}{c}9.8 \\
45.1 \\
45.1\end{array}$ & $\begin{array}{l}18 \\
14 \\
10\end{array}$ & $\begin{array}{l}42.9 \\
33.3 \\
23.8\end{array}$ & $\begin{array}{l}56 \\
71 \\
51\end{array}$ & $\begin{array}{l}31.5 \\
39.9 \\
28.7\end{array}$ & $<0.05^{a}$ \\
\hline $\begin{array}{l}\text { Length of time working in PA programs } \\
\leq 1 \text { year } \\
>1 \text { and } \leq 3 \text { years } \\
>3 \text { years }\end{array}$ & $\begin{array}{c}19 \\
15 \\
8\end{array}$ & $\begin{array}{l}45.2 \\
35.7 \\
19.0\end{array}$ & $\begin{array}{l}20 \\
84 \\
89\end{array}$ & $\begin{array}{l}10.4 \\
43.5 \\
46.1\end{array}$ & $\begin{array}{l}17 \\
13 \\
11\end{array}$ & $\begin{array}{l}41.5 \\
31.7 \\
26.8\end{array}$ & $\begin{array}{l}74 \\
56 \\
31\end{array}$ & $\begin{array}{l}46.0 \\
34.8 \\
19.3\end{array}$ & $<0.05^{a}$ \\
\hline $\begin{array}{l}\text { PET-Health } \\
\text { Did not participate } \\
\text { Participated }\end{array}$ & $\begin{array}{c}39 \\
6 \\
\end{array}$ & $\begin{array}{l}86.7 \\
13.3 \\
\end{array}$ & $\begin{array}{c}183 \\
12 \\
\end{array}$ & $\begin{array}{c}93.8 \\
6.2 \\
\end{array}$ & $\begin{array}{c}43 \\
4\end{array}$ & $\begin{array}{l}91.5 \\
8.5 \\
\end{array}$ & $\begin{array}{c}171 \\
11\end{array}$ & $\begin{array}{l}94.0 \\
6.0\end{array}$ & NS \\
\hline $\begin{array}{l}\text { PRÓ-Health } \\
\text { Did not participate } \\
\text { Participated }\end{array}$ & $\begin{array}{c}40 \\
5\end{array}$ & $\begin{array}{l}88.9 \\
11.1 \\
\end{array}$ & $\begin{array}{c}190 \\
5\end{array}$ & $\begin{array}{l}97.4 \\
2.6\end{array}$ & $\begin{array}{c}43 \\
4\end{array}$ & $\begin{array}{c}91.5 \\
8.5\end{array}$ & $\begin{array}{c}176 \\
6\end{array}$ & $\begin{array}{c}96.7 \\
3.3\end{array}$ & NS \\
\hline $\begin{array}{l}\text { Obligatory internship in PHC } \\
\text { Did not participate } \\
\text { Participated }\end{array}$ & $\begin{array}{l}25 \\
20 \\
\end{array}$ & $\begin{array}{l}55.6 \\
44.4 \\
\end{array}$ & $\begin{array}{c}154 \\
41\end{array}$ & $\begin{array}{l}79.0 \\
21.0\end{array}$ & $\begin{array}{l}32 \\
15 \\
\end{array}$ & $\begin{array}{l}68.1 \\
31.9\end{array}$ & $\begin{array}{c}71 \\
111 \\
\end{array}$ & $\begin{array}{l}39.0 \\
61.0 \\
\end{array}$ & $<0.05^{b}$ \\
\hline $\begin{array}{l}\text { Non-obligatory internship in PHC } \\
\text { Did not participate } \\
\text { Participated }\end{array}$ & $\begin{array}{l}28 \\
17 \\
\end{array}$ & $\begin{array}{l}62.2 \\
37.8\end{array}$ & $\begin{array}{c}146 \\
49 \\
\end{array}$ & $\begin{array}{l}74.9 \\
25.1 \\
\end{array}$ & $\begin{array}{l}32 \\
15\end{array}$ & $\begin{array}{l}68.1 \\
31.9\end{array}$ & $\begin{array}{l}113 \\
69 \\
\end{array}$ & $\begin{array}{l}62.1 \\
37.9\end{array}$ & NS \\
\hline $\begin{array}{l}\text { Curricular experience in PHC } \\
\text { Did not participate } \\
\text { Participated }\end{array}$ & $\begin{array}{l}16 \\
29\end{array}$ & $\begin{array}{l}35.6 \\
64.4\end{array}$ & $\begin{array}{l}119 \\
76\end{array}$ & $\begin{array}{l}61.0 \\
39.0\end{array}$ & $\begin{array}{l}22 \\
25\end{array}$ & $\begin{array}{l}46.8 \\
53.2\end{array}$ & $\begin{array}{c}61 \\
121\end{array}$ & $\begin{array}{l}33.5 \\
66.5\end{array}$ & $<0.05^{c}$ \\
\hline $\begin{array}{l}\text { Scientific initiation in PHC } \\
\text { Did not participate } \\
\text { Participated }\end{array}$ & $\begin{array}{c}37 \\
8\end{array}$ & $\begin{array}{l}82.2 \\
17.8 \\
\end{array}$ & $\begin{array}{c}175 \\
20 \\
\end{array}$ & $\begin{array}{l}89.7 \\
10.3 \\
\end{array}$ & $\begin{array}{c}39 \\
8 \\
\end{array}$ & $\begin{array}{l}83.0 \\
17.0 \\
\end{array}$ & $\begin{array}{c}151 \\
31 \\
\end{array}$ & $\begin{array}{l}83.0 \\
17.0 \\
\end{array}$ & NS \\
\hline $\begin{array}{l}\text { University extension related to PHC } \\
\text { Did not participate } \\
\text { Participated }\end{array}$ & $\begin{array}{c}38 \\
7\end{array}$ & $\begin{array}{l}84.4 \\
15.6 \\
\end{array}$ & $\begin{array}{l}172 \\
23\end{array}$ & $\begin{array}{l}88.2 \\
11.8\end{array}$ & $\begin{array}{l}35 \\
12\end{array}$ & $\begin{array}{l}74.5 \\
25.5\end{array}$ & $\begin{array}{c}140 \\
42\end{array}$ & $\begin{array}{l}76.9 \\
23.1 \\
\end{array}$ & NS \\
\hline
\end{tabular}

*Social assistant, Pharmacy, Nursing, Physical Therapy, Psychology, Occupational Therapy, Nutrition, Phono audiology; a = Significant difference between fully licensed in Physical Education when compared to other categories of initial education. $b=$ Significant difference between licensed and fully licensed in Physical Education when compared to other categories of initial education. $c=$ Significant difference between fully licensed in Physical Education when compared to Bachelor and other categories of initial education.

When information on experience with PHC in initial education are aggregated, we can observe $37.8 \%$ of professionals reporting not having any experiences while in under- 
graduate studies related to PHC, while only $14.1 \%$ reported from 4 to 7 experiences. The proportion of professionals reporting not having experience during initial education is higher among fully licensed (45.9\%) when compared to other categories. On the other hand, the proportion of those with 4 for 7 experiences is higher among bachelors in Physical Education (22.2\%). Stratified information by area of education is showed in figure 2 .

It was observed that three in every ten professionals report not participating in courses, lectures and/or workshops related to PA during the past 12 months and that similar proportion reported participating in over three courses. The proportion of those who did not participate in any action was significantly higher than those in other areas of education when compared to initial education in Physical Education $(\mathrm{p}<0.05)$. Additional information on participation of professionals in courses, events or workshops in the field of physical activity may be observed in figure 3 .

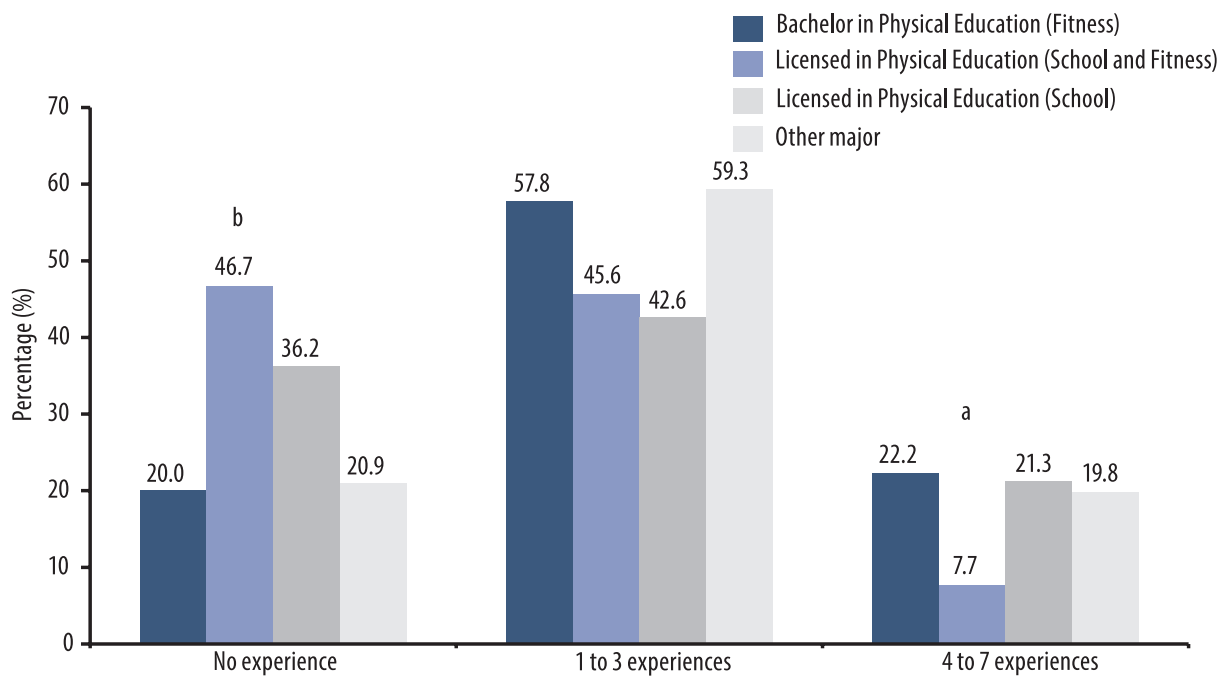

FIGURE 2 - Amount of curricular experiences related to PHC during initial education of professionals with higher education working in programs for health promotion in $\mathrm{PHC}$, with interventions in physical activity in the state of Pernambuco.

$\mathrm{a}=$ Significant difference between fully licensed in Physical Education when compared to other categories of initial education. $b$ = Significant difference between fully licensed in Physical Education when compared to Bachelor and other categories of initial education.

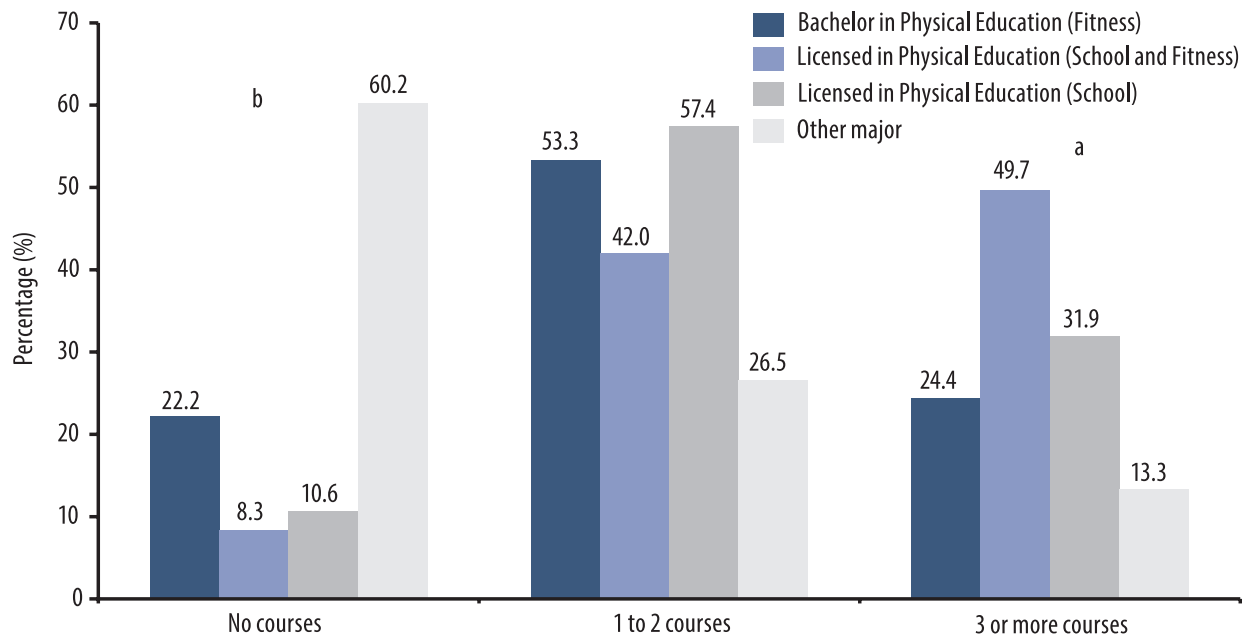

FIGURE 3 - Amount of participation in courses, lectures and/or events, in the past 12 months, related to physical activity and health of professionals with higher education working in programs for health promotion in PHC, with interventions in physical activity in the stat of Pernambuco, by field of education. $\mathrm{a}=$ Significant difference between fully licensed in Physical Education when compared to other categories of initial education. $b=$ Significant difference between other majors when compared to Physical Education. 


\section{Discussion}

In general, most professionals working in programs for health promotion with interventions in physical activity in PHC have higher education, especially in Physical Education (Bachelor in fitness, Bachelor in School Education or Bachelor in school education and fitness). Most have up to three years of experience in the PA program and are employed between programs and have most professionals under temporary contracts. It is believed that in some regions of the State there are even fewer or none offerings for courses of high level education, even more in Physical Education, what can partially explain the considerable proportion of professionals without higher education in determined municipalities. Another aspect is the fact that most employments are done under temporary contract and without a selection process may generate indication of human resource without appropriate training, especially in municipalities considered small. This frailty can be found in both professionals without higher education as well as those with completed high education.

Considering the specificity of the profession, it is a competency of the PEP actions specific to this field of knowledge, however, some authors defend that other health related professionals must care for the population through counseling actions, orientation and indication to PA programs ${ }^{14-16}$. The presence of other professionals with higher education can be tied to NSFH, which proposes as a common action for all professionals to develop PA in the community ${ }^{14}$. In 2004, the technical legitimacy was discussed for the formulation of a State policy in order to guide the education of professionals according to health need of the population, highlighting competencies in education and health sectors in that construction ${ }^{15}$.

A relevant aspect found is that four in every ten professionals reported not having experiences related to PHC during initial education, moreover in the Physical Education courses. In state reality, full licensed professionals are those who have been acting for a longer period and who, during initial education, in most cases did not have the opportunity to live activities related to PHC, disciplines focused on Public Health, such as health promotion, public policies in health, primary health care, among others. It is important to highlight that data indicate a low proportion of professionals with four or more experiences during initial education related to $\mathrm{PHC}$, which show a misalignment with professional experience. The creation of a Bachelor's in fitness and reformation of curriculum in Physical Education courses are recent and seem to have not accompanied the demands for acting in this field ${ }^{17}$. Such data exposes the frailty in education, since, according to Curricular Guidelines, which are common orientation to all professions, high education institutions must assure the flexibility and the quality of education being offered ${ }^{18}$. Beyond offering the undergraduate conditions to overcome challenges of the conditions for professional exercise and production of knowledge, allowing diverse types of education and habilitations within the same program ${ }^{18}$. Curriculum of initial education is a central discussion, since we can observe not only in Physical Education, but also in other areas of education still directed at another attention model ${ }^{19}$.

The participation of professionals in specialization courses is high, while low in multiprofessional residencies. Studies show that Residencies in Health and Multiprofessional in family Health (RMFH) are positive strategies for training professionals with the adequate profile to work in programs proposed by the Ministry of Health, since the new assistance model predicts alterations in education with adequate interpersonal relations, adding psychosocial aspects in interventions and approximation of education with the work field ${ }^{20-21}$. However, few slots are offered to PEP, besides little knowledge from the professionals on the opportunities for continued education in residency courses. 
In the present study it was identified that, among the professionals who look into updating education in PA fully licensed in Physical Education are higher than other professionals. Two arguments may justify this finding that is related to the effectuation of professionals. First, there is the need to access specific knowledge related to skills necessary for professional acting due to initial education not contemplating specific contents nor general contents in primary care. Another aspect is in the type of employment, since most professionals are effective to the Secretary of Health and fully licensed in Physical Education. This scenario may be explained by the position of Physical Education and when the Secretary of Health of Recife/PE, through the bill 17.400 de 28.12.2007, created it, and there were no bachelor's in fitness who had already graduate. Therefore, a public selection conducted in the year of 2008, turned effective professionals in Academia da Cidade (PAC), whom had initial education as full license Physical Education.

According to PNAB, for the consolidation of the reorientation of the model of primary health care in Brazil, it is necessary to promote a knowing and a doing in permanent education that reflect the practice of health services ${ }^{22}$. Among other responsibilities, municipalities and the Federal District, as managers of local health systems, must stimulate and make possible for the capacitation and permanent education of professionals within teams ${ }^{22}$. As expected, the proportion of professional who had not participated in a course, lecture and/or workshop related to PA was significantly higher among those with other majors, when compared to the ones with initial education in Physical Education.

On experience, the minority of professionals had up to a year of professional experience in PHC and in programs for PA promotion. There was a significant difference between professionals with a bachelor of Physical Education in school (licensed) when compared to other professions, on having a state employment status with the Secretary of Health. Such data may be justified due to the Academia da Cidade in Recife being the oldest institutionalized program in the state of Pernambuco, and the type of education allows those fully licensed in Physical Education to work in any context. Programs focused on PA exclusively allows for participation of the PE professional, only. According to the CONFEF resolution $n^{\circ} 046 / 2002$, bill $\mathrm{n}^{\circ}$ 9696/98, it is considered exercise of activities in Physical Education a prerogative of $\mathrm{PE}$ professionals ${ }^{23}$. Moreover, the state reality is that some programs have been coordinated by professionals in nursing, physical therapy, nutritionists, among others, strengthening the need to know the type of initial and continued education on PA, and how capable are they of working in the management of such nature ${ }^{24}$.

Knowing the profile of professional acting in programs and interventions for health promotion with physical activity interventions can contribute to the reorientation of the service. Besides, it is possible to identify a limitation both in initial education as well as in the participation of professionals in continued education courses. The Curricular Guidelines indicate that there should be education in health, as well as an approximation of institutions with the public policy management to contribute to actions from the NPHP being effective.

Beyond principle established and general orientations for undergraduate courses, the Curricular Guidelines in courses for the field of health reinforce the need to articulate between higher education and health systems, with the aim to have a general and specific education of undergraduate students that contemplate promotion, prevention, recovery and rehabilitation in health, where the concept of health is based on principles and guidelines established by the Unique Health System (SUS) ${ }^{18}$.

This study presents potentialities that must be highlighted such as broadness 
and novelty. The SUS+Ativo project visited all municipalities in Pernambuco that were identified with programs (Federal, state and municipal) in PHC that had actions to promote physical activity and all professionals were interviewed, allowing a census. Moreover, a validated, specific instrument was used for evaluation of interventions in physical activity promotion developed in the Primary Health Care System $^{13}$. However, some limitations can be identified. The presence of researchers in the field sometimes was seen as a sort of surveillance. Even when the group of researchers was careful not to, it is believed that it might have inhibited and influenced the answers of some professionals and, therefore, characterize as bias. Another aspect was the extension of the questionnaire that for some, especially professionals without higher education in Physical Education, was not interesting.

Actions taken by management for permanent education strengthens the daily work of professionals. Also, it is necessary that such professionals seek other forms of capacitation, since there were few experiences in PHC during undergraduate courses. Such data also brings out the need for institutions to offer education with opportunities to experience and promote the full development of students to be capacitated and utilize a diversity of knowledge in the field of expertise.

Even though there is a great proportion of professionals with little experience related to PHC and PA promotion while in initial education, a part of them seek to participate in courses, events and workshops focused on physical activity while in exercise of function and even have presented a post-graduate course in the level of specialization Lato Sensu. Continued education may generate contextualization to the professional on their acquired knowledge as well as new meaning to professional experience.

It was observed, in the present study, that investments should be priorities for both initial and permanent education, in order to prepare professionals according to the demands for exercise of function in the public health system. To broaden the vision of the professional redirects the look to a multiprofessional care, strengthening the insertion in public policy programs.

\section{Acknowledgments/ funding}

We thank all of those who contributed direct or indirectly to the project, especially to users, professionals and managers, to GPES and funding agencies (CNPQ, FACEPE and CAPES).

\section{Authors' contributions}

Danyelle de Cássia Ribeiro de Oliveira participated in the concept of the project, writing of manuscript and critical revision of intellectual content. Anísio Luiz da Silva Brito was responsible for analyses and interpretation of data, writing and critical revision of the manuscript. Rafael Miranda Tassitano was responsible for the analyses and interpretation of data, writing and critical revision and approval of version to be published.

\section{References}

1. Ministério da Saúde. National Policy on Health Promotion/Ministry of Health, Secretary of Health Vigilance, Secretaria de Atenção à Saúde. - 3. ed. - Brasília : Ministério da Saúde, 2010.

2. Ministério da Saúde. Redefinition of the National Policy on Health Promotion. Departamento de Análise de Situação em Saúde. Novembro, 2014.

3. Ministério da Saúde. Nucleus for Support to Family Health. Portaria Ministerial de Saúde, nº154, de 24 de janeiro de 2008.

4. Malta DC, Alves da Silva MM, Albuquerque GM, Amorim RCA, Rodrigues GBA, Silva TS, et al. National Policy for Health Promotion, description of implementation of the physical activity axis, from 2006 to 2014. Rev Bras Ativ Fís Saúde. 2014; 19(3): 286-299. 
5. Amorim TC, Knuth AG, Cruz DKA, Malta DC, Reis RS, Hallal PC. Description of municipal programs for physical activity promotion funded by the Ministry of Health. Rev Bras Ativ Fís Saúde. 2013; 18(1): 63-74.

6. CNS. National Counsel of Health. Resolução $N^{\circ} 128$, de 6 de Março de 1997. Disponível em: http://www.portaleducacao.com.br/Artigo/Imprimir/3227. Acesso em 25/11/15.

7. Rodrigues JD, Ferreira DKS, Silva PA, Caminha IO. Insertion and action of the physical education professional in primary health care: systematic review. Rev Bras Ativ Fís Saúde. 2013; 18(1): 5-15.

8. Rodrigues JD, Ferreira DKS, Junior JCF, Caminha IO, Florindo AA, Loch MR. Profile and action of the Physical Education Professional in the Nuclei for Support to Family Health in the metropolitan region of Joao Pessoa, PB. Rev Bras Ativ Fís Saúde. 2015; 20(4) :352-365.

9. Santos SFS, Benedetti TRB. Scenario of implementation of the Nucleus for Support to Family Health and the insertion of the Physical Education professional. Rev Bras Ativ Fís Saúde. 2012; 17(3): 188-194.

10. Scabar TG, Pelicioni AF, Pelicioni MCF. Action of the Physical Activity Professional in the United Health System: an analysis starting from the National Policy for Health Promotion and the Guidelines for the Nucleus for Support to Family Health - NA. J Health Sci Inst. 2012; 30(4): 411-8.

11. Souza SC, Loch MR. Intervention of the physical activity professional in the Nuclei for Support to Family Health in municipalities of northern Parana. Rev Bras Ativ Fís Saúde. 2010; 16(1): 05-09.

12. Freitas FF. Physical Education in the public service [Master's thesis]. São Paulo: Universidade de São Paulo; 2007.

13. Gomes MVG, Lemos EC, Silva JRA, Moura CR, Fonseca SA, Tassitano RM. Evaluation of programs and interventions for physical activity promotion in primary health care in Pernambuco: construction and validation of instruments and fieldwork methods of the SUS+Ativo Project. RBAFS, No prelo.

14. Jacobson DM, Strohecker L, Compton MT, Katz DL. Physical Activity Counseling in the Adult Primary Care Setting. Am J Prev Med. 2005; 29(2): 158-62.

15. Ceccim RB, Feuerwerker LCM. Change in majors of health professions under the axis of integrality. Cad. Saúde Pública. Rio de Janeiro. 2004; 20(5):1400-1410.

16. Orrow G, Kinmonth AL, Sanderson S, Sutton S. Effectiveness of physical activity promotion based in primary care: systematic review and meta-analysis of randomized controlled trials. British Journal of Sports Medicine. 2012; 47(1): 27.

17. Andrade DR, Costa EF, Garcia LMT, Florindo AA. Education of the bachelor in Physical Education against the situation of health in Brazil. In: Benedetti TRB, Silva DA, Silva KS, Nascimento JV (ORG). The Education of professional of Physical Education for the health sector. Florianópolis: Postmix. 2014; 89-107.

18. Brasil. Ministério da Educação. Comments from the National Counsil in Education. Câmara da Educação Superior no 213/2008. Disponível em: http://portal.mec.gov.br/ cne/arquivos/pdf/2008/pces213_08.pdf. Acesso em 05/11/215.

19. Haddad AE, Morita MC, Pierantoni CR, Brenelli SL, Passarella T, Campos FE. Education of health professionals in Brazil: an anlysis from 1991 to 2008. Rev. Saúde Pública. 2010; 44(3): 383-393.

20. Anjos TC, Duarte ACGO. Physical Education and the Strategy for Family Health: education and action of the professional. Physis: Rev Saude Colet. 2009; 19(4): 1114-1127.

21. Nascimento DDG, Oliveira MAC. Reflections on the professional competencies for the work process in Nuclei for Support to Family Health. Mundo Saúde. 2010; 34(1): 92-6, 2010.

22. Brasil. Ministério da Saúde. Secretary of Attention to Health. Política Nacional de Atenção Básica / Ministério da Saúde. Secretaria de Atenção à Saúde. Departamento de Atenção Básica. - Brasília: Ministério da Saúde, 2012.

23. CONFEF. Federal Counsil oh Physical Education. Disponível em: http://www.confef. org.br/extra/resolucoes/conteudo.asp?cd_resol=82. Acesso em 24/11/15.

24. Silva JRA. Practice for monitoring and evaluating interventions in physical activity promotion in primary health care in the state of Pernambuco [Master's thesis]. Recife: Universidade de Pernambuco, 2015.

CORRESPONDING

AUTHOR

DANYELLE DE CÁSSIA RIBEIRO DE OLIVEIRA

cassiaom77@yahoo.com.br
Avenida Beberibe, $\mathrm{n}^{\circ} 3530 / \mathrm{Bl}-\mathrm{B} 7-$

Apt ${ }^{\circ} 103$-Porto da Madeira, Recife - PE

Zip code: $50100-130$

Phone number: +55 (81) 3183-

3375/3183-3376 